UDC 332; DOI 10.18551/rjoas.2022-01.02

\title{
LEGAL PLURALISM OF SPATIAL RIGHTS OF INDIGENOUS PEOPLE IN ARCIPELAGIC PROVINCE IN INDONESIA
}

\author{
Sinay Siti Barora* \\ Faculty of Law, Khairun University, Ternate \& Doctoral Program of Faculty of Law, \\ University of Brawijaya, Malang, Indonesia
}

Nurjaya I Nyoman, Koeswahyono Imam, Safa'at Muchamad Ali, Lecturers

Faculty of Law, University of Brawijaya, Malang, Indonesia

*E-mail: sinaysitibarora@gmail.com

\begin{abstract}
Conditional recognition of customary law communities and their traditional rights in Article 18B paragraph (2) of the 1945 Constitution of the Republic of Indonesia weakens the position of indigenous peoples in the fulfillment and protection of spatial planning rights as the operationalization of beschikkingrecht from the values of justice and welfare which are the goals of national development. This research is normative legal research that analyzes customary law community rights in living space as regulated in Law Number 26 of 2007 and Law Number 27 of 2007 based on the theory of legal pluralism. The results of the study show that (1) the relationship between the customary law community and the living space is magical and religious, which creates awareness of adaptation to maintain the balance of the cosmos through devotion/can in the form of rituals that are adhered to based on customary values (customary decisions) regarding the right to regulate, organize allotments and use and maintain the sustainability of living space, an ancestral heirloom. (2) The management of the living space and resources of the indigenous peoples of the archipelagic province in Indonesia reflects weak legal pluralism. Therefore it is necessary to recognize the customary law communities through harmonization and formulation of norms for the recognition of customary law communities, territories, rights of legal subjects, as well as the concept of one map in the revision of the Spatial Planning Law and the Employment Creation Law as well as encouraging the acceleration of the bill on customary law communities as lex specialis for the recognition and protection of indigenous peoples in Indonesia.
\end{abstract}

\section{KEY WORDS}

Customary law communities, spatial planning rights, archipelagic provinces.

The State of Indonesia is an archipelagic country characterized by an archipelago as stated in Article 25A of the 1945 Constitution of the Republic of Indonesia, consisting of a group of islands stretching from Aceh to Papua with an area of 7.81 million $\mathrm{km}^{2}$ comprised of a land area of 2.01 million $\mathrm{km}^{2}$ and a coastline length of 2.01 million $\mathrm{km}^{2}$. The beach stretches to reach $95,186 \mathrm{~km}^{2}$ which is united by the ocean. With the geographical characteristics of the islands, the distribution of ethnic groups occurs in coastal areas, which are the place for the development of a coastal culture that extends from the islands to the interior.

The implementation of regional autonomy in archipelagic countries has taken into account the specifics of regional morphology as affirmed in Article 1 number 19 of Law Number 23 of 2014 concerning Regional Government, namely provinces that have geographical characteristics with an ocean area more expansive than the land area in which some islands form a cluster. The island so that it becomes a geographical and socio-cultural unit, with regional government authorities as regulated in Article 27 to Article 30 covering the power to manage natural resources, budgeting, and strategic priorities for regional development acceleration consisting of (1) development priorities and natural resource management at sea; (2) acceleration of economic development; (3) socio-cultural 
development; (4) human resource development; (5) development of customary law related to marine management; and (5) community participation in regional development.

In the archipelagic province, customary law communities resided long before the Republic of Indonesia was formed which were then accommodated by the state as legal subjects of citizens, recognized and respected by the state in the constitution as referred to in Article 18B paragraph (2) of the 1945 Constitution of the Republic of Indonesia which formulated the recognition of conditional constitutionality that "The state recognizes and respects customary law community units and their traditional rights as long as they are still alive and in accordance with community development and the principles of the Unitary State of the Republic of Indonesia, which are regulated by law".

Spatial planning as the spatial dimension of national development planning in archipelagic provinces based on Law Number 26 of 2007 concerning Spatial Planning and Law Number 27 of 2007 concerning Management of Coastal Areas and Small Islands as amended by Law Number 11 of 2020 concerning Job Creation. in stages as a process system that includes spatial planning, space utilization, and space utilization control. Spatial planning policies in the development planning system are implemented through the Regional Spatial Planning and Detailed Spatial Plans, which are the direction of development implementation that utilizes space in the long term. In contrast, the utilization and control of space utilization are based on zoning regulations. This means that the state's implementation of spatial planning/management is intended for the greatest prosperity of the people through national development, which is carried out in stages and planned based on government authority, consistently and sustainably so that regional space can be used effectively and sustainably. Empirical reality shows that customary law communities that have existed from generation to generation are increasingly marginalized and marginalized for reasons of development and modernization through the exploitation of land and sea space (forest and coastal/sea), which not only threatens the sustainability of economic life but also causes distortion of the noble values of wisdom. Local indigenous peoples maintain the sustainability of lebensraum as a gift from God Almighty.

Beschikkingrecht in this customary area gives authority to customary law communities to manage land, water, and resources according to their needs based on a system of knowledge and equipment that contains the value of justice and adequacy in customary rules regarding the extraction of natural resources accompanied by rules and prohibitions. Overexploitation is aimed at maintaining the sustainability of living space and its contents.

The ideal hope to develop state law, especially spatial planning law, is still far from fulfilling the values of Pancasila (philosofische grondslag), which are in harmony with values that live and develop and become the soul of the nation (volkgeist). Spatial planning law, which is supposed to be a spatial instrument of national development as a means of realizing the country's goals, is experiencing a globalization bias that is substantially far from the ontology, epistemology, and axiology frameworks, mainly related to respect for indigenous peoples and values that live and develop in interpreting and managing space life (lebensraum) as an ecological unit.

This study aims to analyze the existence of the spatial rights of indigenous peoples living in the archipelagic province, which are dubbele beschikkingskring which utilize land and sea space as an ecosystem unit, based on the diversity of customary law, as well as conditional recognition of customary law communities and their traditional rights by the state not directly proportional to the legal politics of natural resource management and spatial planning with a centralized pattern. The legal issues in this paper include 1) The philosophical meaning of the cultural existence of spatial rights for indigenous peoples in the archipelagic provinces in Indonesia, and 2) How is the construction of legal pluralism as a system for protecting the spatial rights of indigenous peoples in Indonesia.

\section{METHODS OF RESEARCH}

This paper is part of normative legal research, which, according to Peter Mahmud (Mahmud, 2007) as a process to find the rule of law, legal principles, and legal doctrines to 
answer the legal issues faced through arguments, theories, or new concepts as prescriptions in solving legal problems. In analyzing the legal issues in this paper, the conceptual approach and the statute approach are used.

The conceptual approach is carried out to analyze the views and doctrines that develop in the science of law, namely analyzing the legal diversity that lives in customary law communities based on the concept of legal pluralism by Werner Menski and Jhon Griffiths. In contrast, the Statute approach is carried out by examining the legislation relating to indigenous peoples and spatial planning is based on an understanding of hierarchy and general principles, namely lex superior derogate legi inferiori and lex specialis derogate legi generali.

\section{RESULTS AND DISCUSSION}

With the geographical characteristics of archipelagic provinces according to Article 1 number 19 of Law Number 23 of 2014, which grammatically shows the morphology of landforms surrounded by water (in the sea, in rivers, or lakes) of a specific size, alone or forming groups, then based on the Ministerial Regulation Domestic Affairs Number 137 of 2017 concerning Codes and Data for Government Administration Areas as well as provincial, regional profiles, it was found that 16 (sixteen) provinces are archipelagic provinces, including Bangka Belitung Islands; Riau islands; DKI Jakarta; East Java; Banten; Bali; West Nusa Tenggara; East Nusa Tenggara; North Sulawesi; Central Sulawesi; South Sulawesi; Southeast Sulawesi; West Sulawesi; Maluku; North Maluku; and West Papua.

The spread of this customary law community initially occurred in coastal areas (coastal culture) then expanded to the islands to the interior. This alliance by Soepomo, based on its composition, formed 2 (two) legal alliances, namely based on genealogical ties, namely legal alliances that occurred based on kinship according to the patrilineal, matrilineal, or parental arrangement; and based on the regional environment (territorial) where the membership of the alliance is determined by the place of residence/region (Soepomo, 2013).

Indigenous peoples refer to rechtsgemeenschappen which Ter Haar Bzn (Haar, 2013) formulated as "organized groups of permanent character having their material and immaterial property" (Haar, 2013). Holleman states the conception of Van Vollenhoven (Holleman, 1981) that " the term is here rendered as jural communities...derive their distinct, legal autonomy in the domestic affair from the fact that each has (a) its discrete representative authority, and (b) its discrete communal property especially land, over which it exercises control (Holleman, 1981).

State recognition of the existence of zelfbesturende landschappen and volksgemeenschappen and archipelagic characteristics shows the existence of a pluralistic alliance that is original throughout the archipelago, which has developed into autonomous regions that are special or special or also use the terminology of regional morphological characteristics. This plurality of origins is accommodated through Article 18B paragraph (2) of the 1945 Constitution of the Republic of Indonesia as a necessity for the state's appreciation of indigenous peoples who are far away and together form the state even though they are attached to the conditions "as long as they are alive", "according to the development of society", "according to the principles of the Unitary State of the Republic of Indonesia" and "regulated by law".

The mapping of the Central Statistics Agency (Sub-Directorate of Political and Security Statistics, 2017) on the existence of indigenous and tribal peoples in 2010 identified an ethnic/ethnic distribution reaching 1,340 ethnic groups. However, AMAN identified around 70 million indigenous peoples divided into 2,371 indigenous communities that spread across 31 provinces of the country, as well as the mapping of indigenous peoples in coastal areas and small islands conducted by the Ministry of Maritime Affairs and Fisheries, identified 49 communities that have been facilitated since 2016-2020.

Ter Haar Bzn describes the relationship between customary law communities and their living spaces and Van Vollenhoven in the form of customary rights (beschikkingsrecht) as legal institutions and the concrete legal relationship between customary law communities and 
lebensraum as fundamental rights to freely take advantage of their living space including crops, water, and other resources. The "beschikkingrecht" environment can also be found to be dual (dubbele beschikkingskring), which is an environment in the form of a hamlet in the interior as an area that is inhabited and harvested for living and besides that, even though it is far away there is an environment along the sea, where the hamlet takes marine products and necessary salt.

We can find the management of living space in res communes by indigenous peoples in several archipelagic provinces in Indonesia, such as Popah (Bengkalis, Riau), Tano (Nias), Wewengkon (Java), Leuweung Kolot (Baduy, Banten), Prabumian and Payar (Bali), Paer (Lombok), Totabuang (Bolaang Mongondow), Limpo and Tongkonan (South Sulawesi), Petuanan (Ambon), Nuru (Buru), Aha/Hale (North Maluku), performed with a religious magical value order that shows the relationship between humans with the macrocosm and microcosm in the trilogy of relationships between humans, God, and nature as internalized in customary law (Sinay et al, 2021).

The Philosophical Meaning of The Cultural Existence of The Spatial Rights of The Indigenous Peoples of The Archipelagic Province in Indonesia. Living together in society embodies norms, value systems, behavior/attitudes, creativity, intentions and feelings by Clyde Kluchkohn in his book "Universal Categories of Culture" as quoted by Koentjaraningrat namely "(1) language; (2) technology systems; (3) economic system; (4) social organization; (5) knowledge system; (6) arts; and (7) the religious system, which are elements of human adaptation to the natural environment to produce a dynamic balance (Koentjaraningrat, 2005).

The existence of a law that lives in customary law communities is a reality of a pluralistic nation as a gift from God Almighty with religious and communal magic, which is abstracted into the values of Pancasila, which contains the paradigm of legal pluralism, which contains the values of protection for all citizens and their rights. Their rights to achieve just and equitable welfare goals.

Spatial rights are rights institutions that become the operationalization of customary rights (beschikkingsrecht) which Van Vollenhoven defines as the fundamental right of the legal community to freely utilize and manage all land, water, and other resources within its territory (Holleman, 1981). Spatial planning rights are the authority of indigenous peoples to regulate, plan, utilize, and control the sustainability of their living space and resources for future generations in accordance with their respective customary laws.

The ontology aspect relates to the value of justice and the value of humanity for the gift of God Almighty, which must be respected and protected as a form of respect for humanity carried out by the state. The legal ontology, according to Jan Gijssels and Mark van Hoecke is "a whole series of fundamental problems that are presented as relations between humans in a collection of people (maatschap) and the form of fellowship (gemeenschap, community, and society) as well as humans themselves in their juridical aspects. Thus, the nature of the law exists in the relationship between humans and between humans and their environment or nature (Rhiti, 2011).

These gifts include the existence of indigenous peoples who are part of the nation's citizens created with a diversity of universal cultural elements. On the other hand, the gift of territory in the form of an archipelagic state saves the wealth of agro-maritime natural resources in remote corners of the archipelago as a national development capital which is placed in the concept of the right to control the state as a policy path to realize the legal ideals contained in the fourth paragraph of the opening of the 1945 Constitution where the gifts of the earth, water and wealth Nature in the Indonesian homeland must be utilized to achieve the greatest prosperity and justice for all the people.

Customary territory as a living space (lebensraum) of customary law communities means three dimensions as a dwelling house that must be arranged as well as possible for the happiness, welfare, and sustainability of mankind. This is understood because human life is very dependent on living space which provides a variety of absolute needs for humans, such as air, water, sunlight, and various types of natural resources. Living space is a 
condition sine qua non for humans where nature and living space are an inseparable unity in supporting life on earth.

Customary law in customary law communities as an order of traditional knowledge is based on a religious system that contains truth values that are upheld, understood, and followed consciously by all members of the alliance as conveyed by their ancestors through speech culture. The knowledge referred to has a magical cosmic pattern that views humans as part of their natural environment who is obliged to maintain their relationship with the universe as a form of cosmic balance and socio-cultural balance.

The epistemological aspect is related to how customary law communities inherit traditional knowledge through the mechanism of a magical religious, cultural system in interpreting the existence of the power of creator, nature, and humans individually and collectively, which is maintained in the balance of life. Likewise, a State that accepts people's sovereignty adapts cosmological values as a posteriori knowledge to ensure the sustainability of the living space for the nation's children in a sustainable manner.

With an understanding of the philosophy of customary law that sees living space in a religious communalistic conception a priori, it creates awareness of adaptation to the balance of the relationship between the external world and the inner/unseen world, so that by using traditional sources of knowledge, namely God, gods, and ancestral spirits, indigenous peoples believe that the existence of a fellowship living space in its dimensions there are heirlooms which are the abodes or dwelling places for ancestral spirits and gods/Gods. Belief in the truth of the existence of absurd things through sensory experience relating to God/gods or ancestral spirits directly or through intermediaries (natuur as a source of knowledge) is manifested in the form of rituals to seek approval, protection including forgiveness.

The practice of managing space by customary law communities is guided by customary law, which contains magical religious values that still exist for legal communities in several archipelagic provinces in Indonesia such as adat (melayu, Riau), pikukuh karuhun (Badui, Banten), tatali paranti karuhun (Kasepuhan, Banten), awig-awig (Bali), sawen (Lombok), lilifuk (NTT), ammana gappa (Bugis, Sulawesi Selatan), ombo (Sulawesi Tengah), eha (Sangihe, Sulawesi Utara), sasi (Maluku), yotatau yutut (Maluku Tenggara), and abanfan matilon (Papua Barat) are social institutions that are embodied in symbols as a form of communication or expression of sacred messages regarding a community view of life.

The existence of customary law serves as a guide for macro-cosmic and micro-cosmic relations, which are embodied in a system of religion and belief as well as a knowledge system to understand the universe as a form of devotion (bhakti/tapa) to God/gods/spirits that are believed to be. Thus, indigenous peoples express this devotion/tapa through rituals related to the journey of life such as birth, marriage, death, for example, manusia nyadnya (Bali), pamangu ndewa (NTT), joko kaha (Ternate), and amfendipana (Papua Barat), as well as rituals related to the management of space and its resources, such as: ngamumule pare (Kasepuhan Banten), ngabaratakeuan and ngareremokeun (Badui, Banten), melasti (Bali), penti (Manggarai NTT), tulude (Sangihe), sasi (Maluku), tolagumi (Maluku Utara), and abanfan matilon (Papua Barat).

The axiological aspect is related to the nature of the value of use and the existence of the purpose of a value. The values contained in customary law are the basic rules for customary law communities to benefit from their living space, as well as the value of the usefulness of state authority according to Article 33 paragraph (3) of the 1945 Constitution of the Republic of Indonesia through structuring/management of space in carrying out legal functions as a means to deliver Indonesian people towards prosperity, including the archipelagic province.

The procedures used by customary law communities have become traditions that contain traditional wisdom values in maintaining the balance of life, which Otje Salman believes is based on the belief of the customary law community that "the imbalance that occurs in the relationship between the outer world and the inner world is directly proportional to the imbalance at a larger level, namely the universe (macro cosmos) (Permana, 2006). In this context, habits that occur repeatedly are then turned into laws as behavioral guidelines 
applied by traditional leaders. The customary law in customary law communities contains orders to maintain the balance of life and contains threats for violations that are believed to be reinforcements/curses/powers of wrath from God/gods or spirits.

In addition to believing in the macro-micro cosmos balance as a value system, indigenous peoples also believe that their presence in creation is an integral part of the alliance as is the hallmark of the commun, so that the collective interests of indigenous peoples become the main concern as a mandate/message from their ancestors. This belief also underlies the operation of knowledge systems and equipment systems in customary ownership areas (petuanan, wewengkon, totabuan, ulayat, payar, and other names), which contain the value of justice and adequacy in customary rules regarding the extraction of natural resources accompanied by rules and prohibitions on exploitation excessive (pantang larang, tabu, buyut, pamali, itang, sasi, and other names) which aims to maintain cosmological harmony (sustainability of living space and its contents).

The rituals and prohibitions that are obeyed are intended to carry out customary law to obtain protection from God/gods/spirits and to avoid bad luck/disasters. In all forms of customary law communities, this concept is the basis of life which believes that the source of livelihood comes from the generosity of nature, which is a gift from the creator. Therefore the salvation of life can be achieved through the simplicity of devotional service and asceticism.

Tapa/bhakti for indigenous peoples is a concrete relationship between humans, nature, and the creator based on customary law as a form of gratitude, asking for protection and preventing disaster. This adherence to customary values was born from the belief in customary law, which is accepted as truth, for example, Baduy cosmology which is based on pikukuh karuhun related to living space, among others: "gunung teu meunang dilebur (mountains must not be destroyed/destroyed), lebak teu meunang diruksak (the valley must not be destroyed), larangan teu meunang dirempak (the prohibition must not be violated), buyut teu meunang dirobah (the taboos could not be changed) " (Permana, 2006) Likewise, Balinese manners adhere to sad kerthi as "an effort to purify the soul (atma kerthi), preserve forests (wana kerthi) and lakes (danu kerthi) as a source of clean water, sea and beaches (segara kerthi), social harmony and dynamic nature (jagat kerthi), and build the quality of human resources (jana kerthi)" (Wiana, 2018).

Prohibitions/taboos related to natural resources can also be seen in the practice of using resources in spaces designated for conservation for a certain time, for example in the practice of sasi adat in Maluku and Papua (abanfan matilon) which is manifested through the ritual of opening/closing sasi accompanied by a marker symbol (coconut leaf sticks) and prayers by traditional leaders. Likewise with the eha ritual in Talaud in certain months for forest and marine products which becomes a ritual with a series of mangolom para (asking for prayer) and the use of forest rope and coconut leaf fishing gear (sammi) to produce catch for all community members (Satria et al., 2017).

This shows that a priori beliefs and a posteriori experiences raise awareness that is accepted as truth which contains the value of goodness and psychological beauty that forms the soul of law to view forest and water resources as living spaces (lebensraum). Furthermore, the legal spirit of this lebensraum then becomes the principles as the basis for the use of living space which is concreted through customary decisions.

The description above shows that customary law communities in archipelagic provinces in Indonesia who depend on land and sea living spaces (dubbele becschikkingskring) who still exist carry out customary law values in managing lebensraum, which contain the value of macro-micro cosmos balance, which is operationally institutionalized into Spatial planning rights as the rights of indigenous peoples in the implementation of sustainable spatial planning/management by the state.

The customary law values that are believed and exist in the customary law community in Indonesia show a construction that is in line with the receptie theory by Snouck Hurgronje followed by van Vollenhoven, where the core of this theory states that "laws that live and apply to the Indonesian people regardless of their religion. is customary law, the reception of religious law into and applies as long as customary law requires" (Soemardiningrat, 2011). This can be seen from the reception of some religious laws (Islam, Hinduism) in 
arrangements relating to marriage and resource management which are symbolized through prayer rituals according to religious teachings, including sanctions.

Legal pluralism as a system for protecting the spatial rights of indigenous peoples in the archipelagic province in Indonesia. In the decision of the Constitutional Court Number $35 / \mathrm{PUU}-\mathrm{X} / 2012$, the court believes that the general welfare as the goal of the state is intended as the welfare of all Indonesian people who are pluralistic (including the diversity of indigenous and tribal peoples) and bind themselves to form an independent state. Thus, Article 18B paragraph (2) of the 1945 Constitution of the Republic of Indonesia contains an affirmation that customary law communities are constitutionally recognized and respected as rights holders, which of course can also be burdened with obligations, so that as legal subjects they must receive the attention of the state when the law wants to regulate, especially regulating in the context of allocating the resources of life.

As a sovereign state of the people, legal development should refer to the moral principles of the people, which mandate the existence of the state as a guarantor for the protection of all of Indonesia's bloodshed. If it is related to morals, then Indonesian law must be able to guarantee that the territory of Indonesia is a living space where the entire pluralistic Indonesian nation, without exception of the customary law communities living in the archipelagic province, can feel protected, peaceful, and just in plurality as an existential reality.

Thus, the spirit of Indonesian law must be placed on the state as a guarantor of human rights, including recognizing the validity of customary law according to Moh. Djojodigoeno (Erwin, 2018) reflects what people believe is a view of life that is under the feeling of justice and propriety (Erwin, 2018). These human rights cannot be separated from the values contained in the core layer of customary law itself, namely custom itself, which is the basis/direction for the life of indigenous peoples.

This is in line with the view of Jimly Assiddiqie (Assiddiqie, 2017) that the second principle of "Just and Civilized Humanity" must be understood that the state is nothing but a human organization, by humans, and for Indonesian people so that building a country is identical to building Indonesian people wherever they are (forest, interior, coastal, urban, rural, big island, small island) have the right to receive humane treatment (fair and civilized) which is based on divinity and justice which is firmly rooted in the noble values of the nation's culture but dynamically adapts to the development of human civilization in the world. (Assiddiqie, 2017).

Spatial planning is the operationalization of Pancasila's goals related to regional space and sustainable resources to the welfare and prosperity of the Indonesian people. Still, if studied more deeply, Law Number 26 of 2007 narrowed to mere technical and administrative issues in land space (Koeswahyono, 2012). On the other hand, the marine, coastal and small islands that constitute the morphology of the archipelagic province is regulated in Law Number 27 of 2007 are more progressive in formulating a framework for protecting the rights of indigenous peoples concerning the recognition of the existence of indigenous peoples as referred to in Article 61 which states that the government recognizes the existence of indigenous peoples, respecting and protecting the rights of indigenous peoples and local wisdom that have been used for generations, this recognition is used as a reference in the management of coastal areas and small islands.

By looking at the diversity of customary law styles that are still adhered to by the indigenous peoples of the archipelagic provinces that still exist in Indonesia, this is in line with the view of Jhon Griffiths (Nurjaya, 2008), which states that "legal pluralism is the fact. Legal centralism is a myth, an ideal, a claim, an illusion. Legal pluralism is the name of a social state of affairs, and it is a characteristic which can be predicted of a social group" (Nurjaya, 2008). This concept is intended to highlight the existence and interaction of legal systems in a society, between state law and folk law and religious law in a community.

Indonesia has been very accustomed to living in a legal pluralism that has developed from the diversity of community classifications since the Dutch colonial era. Customary law as living law is conceptualized as a legal system that is formed and derived from the empirical experience of past communities, which is considered fair or appropriate and has 
received legitimacy from customary authorities so that it is binding or must be obeyed (normative).

The formulation of the norms of Article 18B paragraph (2) of the constitution, which is conditional in the theory of legal pluralism, shows a pattern of weak legal pluralism, which is another form of legal centralism, where even though there is an acknowledgment of the existence of other legal systems, state law has a superior position. In contrast, other legal systems have a superior position. Other laws are inferior in the hierarchy of the country's legal system. Thus, the recognition of customary law communities by the state must go through the stages of identification, verification and validation, and determination by a Regional Head Decree as regulated in the Minister of Home Affairs Regulation Number 52 of 2014 concerning Guidelines for Recognition and Protection of Indigenous Peoples.

Regarding the spatial rights of indigenous peoples living in forest and inland areas, Law Number 26 of 2007 is not accommodated, including its amendments. Still, for customary law, communities whose living space is on the coast and the sea are accommodated through Law Number 27 of 2007 and its amendments. On the other hand, Law Number 11 of 2020 concerning Job Creation was declared conditionally unconstitutional through the decision of the Constitutional Court number 91/PUU-VIII/2020, where the articles in the Act are still declared valid within a grace period of 2 (two) years. The law, which was formed using the omnibus law method, reduces regional governments' authority in spatial planning/management, mainly related to space utilization permits and the review of regional spatial plans.

Article 18 number 26 (Article 60 paragraph 1) of the Job Creation Law states that the state recognizes the rights of communities, including customary law communities, in the management of coastal areas and small islands, including:

- gain access to parts of coastal waters that have obtained business permits related to utilization at sea;

- obtain benefits from the management of coastal areas and small islands;

- obtain information regarding the management of coastal areas and small islands;

- submit reports and complaints to the competent authorities for the losses that have occurred him related to the implementation of the management of coastal areas and small islands;

- express objections to the management plan that has been announced within a certain period;

- report to law enforcement as a result of suspected pollution, pollution, and/or destruction of coastal areas and small islands that are detrimental to their lives;

- file a lawsuit to the court against various problems of coastal areas and small islands that are detrimental to their lives;

- obtain compensation; and

- receive legal assistance and assistance on the problems faced in the management of coastal areas and small islands in accordance with the provisions of the legislation.

In addition to the rights of the people above, the Job Creation Act expressively formulates regulations regarding customary law communities, including:

- propose the customary law community management area into the RZWP3K;

- exemption from business licenses in customary management areas;

- carry out the management of coastal resources and small islands based on applicable customary law and do not conflict with statutory provisions.

The description above shows that Law Number 27 of 2007 pays attention to and accommodates customary law communities in the norms of managing coastal areas and small islands, but this is not the case with Law Number 26 of 2007, which is included in the national legislation program in the same year and is only for a short term 3 (three) months at the time of promulgation. This illustrates the inconsistency and incomprehensibility of the legislators in formulating the provisions for the use of space for legal subjects, especially customary law communities, only in coastal areas and small islands, which means ignoring the existence of customary law communities in land space management. 
In the management of natural resources, it shows the existence of legal pluralism involving different legal systems, namely "state law" and "customary law" according to Maria S.W. Sumardjono shows weak legal pluralism because it places the dominance of state law as reflected in the formulation of legislation related to natural resources that limit the application of other legal norms outside state law through the phrase "as long as it does not conflict with the laws and regulations" (Sumardjono, 2018). Whereas the existing legal systems contribute to the development of national law, according to Kurnia Warman, "Adat and Islamic laws have greatly contributed to the enrichment of the Indonesian legal system. Despite this contribution and the existence of some constitutional recognition, however, both adat and Islamic laws remain under the control and domination of the national law. This makes it difficult for a strong legal pluralism (Warman, 2018).

Whereas as the spatial dimension of national development, the state's authority in managing the territorial sovereignty of Indonesia through sustainable development requires a legal conception that can direct equitable development for welfare as rights-based development (Latif, 2012).

This authority is a condition sine qua non for the government and the legislature to strengthen the integration of the nation and the Republic of Indonesia through the development of national law by reorienting the legal development paradigm with a legal centralism pattern to legal pluralism, which provides a space for recognition and protection that is complete and genuine for the existence of legal systems (customs and religion) including the inner order mechanism in people's lives. In further development, I Nyoman Nurjaya stated that "the concept of legal pluralism no longer emphasizes the dichotomy between state law and folk law and religious law on the other hand". At this stage of development, the concept of legal pluralism places more emphasis on the interaction and coexistence of various legal systems that affect the workings of legal norms, processes and institutions in society" (Nurjaya, 2008).

Through the authority of the regional government of the archipelagic province as regulated in Article 28 of Law Number 23 of 2014, which states the authority to manage natural resources at sea and the authority that comes from the assistance task of the central government. The authority to manage natural resources includes spatial planning, as stated in paragraph (2) letter c, specifically in government regulation.

Thus, to realize the goal of community welfare with the diversity of customary law, the state must devote itself to accommodating the rights of indigenous peoples as Jawahir Thontowi views that "for the sake of the future, recognition, and respect for community (village) autonomy is intended to answer the future, especially responding to the process of globalization, which is marked by the process of liberalization (information, economy, technology, culture, etc.) and the emergence of economic players on a global scale. Global capitalists' impact of globalization and exploitation is impossible for localities to deal with, even with adequate autonomy. This challenge requires stronger institutions (in this case the state) to deal with it" (Thontowi, 2013).

The determination of customary law communities by local governments to be the entry point for customary law communities in the management of lebensraum and natural resources in archipelagic provinces is based on a customary law system that contains magical religious values so that it is in harmony with Pancasila, which is based on customary law. Within the framework of protecting the spatial rights of indigenous peoples in customary areas, the state will give respect to the ownership of the living space of indigenous peoples whose philosophical dimensions, ideological dimensions are a manifestation of selfconfidence, beliefs and ideals as part of the Indonesian nation as well as a political dimension that contains the power and authority over the position and social role of indigenous peoples in their customary territories.

Therefore, operationally, the spatial rights of customary law communities contain the authority to regulate and organize space allocations in accordance with existing customary law values, including ownership and management rights over existing resources in the lordship area as well as the preservation of the sustainable function of lebensraum as a form of asceticism devotion to God/Gods/Spirits/Ancestors. Spatial rights of customary law 
communities, which are based on an ecological understanding and appreciation of nature, show a pattern of mutual care, compassion and fairness for all members of the alliance as a form of moral attitude and behavior that underlies all stages of spatial planning, namely planning, utilization and control of utilization room.

Indigenous peoples of the archipelagic province depend on land and sea for their lives as a unitary space. Nature (land, sea, and air) is a fundamental unit of human life. Thus, the implementation of spatial planning in an archipelagic state must contain the principle of spatial unity, which implies maintaining the ecological relationship of the bio-ecoregion in the planning, utilization, and control of spatial planning. This principle is the basis for the one map policy in Law Number 11 of 2020 , which is technically realized through integrating the Zoning Plan for Coastal Areas and Small Islands into the Provincial Spatial Planning.

In line with the discussion of the draft law on customary law communities as the 19th priority in the 2020-2024 national legislation program, it is hoped that more progressive arrangements regarding the stages of recognition of customary law communities, the scope of protection for customary areas related to communal ownership, management rights and territorial conservation are expected as well as legal subjects related to the spatial rights of customary law communities at the stages of planning, utilization, and control of space.

On the other hand, the revision of Law Number 11 of 2020 relating to spatial planning that is accommodating to customary law communities can be carried out through the formulation of norms in Law Number 26 of 2007, including: (1) recognition and protection of indigenous peoples; (2) spatial planning rights of customary law communities to customary areas in the spatial planning stage; and (3) the principle of spatial unity and the concept of one map policy as an integrated form of spatial planning.

\section{CONCLUSION}

Based on the description in the previous section related to legal pluralism as a way to realize the welfare of customary law communities through the recognition of the existence of customary law communities, including spatial planning rights, it is concluded as follows:

1) Customary law communities as part of citizens who receive constitutional guarantees as stipulated in Article 18B paragraph (2) of the 1945 Constitution of the Republic of Indonesia have a magical, religious and communal relationship with customary territories based on various customary law values. Ontologically, spatial planning rights are attached to living spaces as conditio sine qua non as a gift from God the creator. This truth epistemologically creates awareness of adaptation to the macromicro cosmos balance through devotion/tapa in the form of rituals asking for approval, protection and/or forgiveness which aims to maintain the sustainability of the source of livelihood through the observance of customary value institutions which are concreted through customary decisions regarding the right to regulate, organize and use the allocation and maintain the sustainability of living space which is an ancestral heirloom;

2) To realize the goal of community welfare by looking at the facts of the diversity of customary law, legal pluralism is one of the legal solutions to accommodate the spatial rights of indigenous peoples as the operationalization of customary rights through the recognition of customary law communities. In the condition of weak legal pluralism in Indonesia, the spatial rights of indigenous peoples in the archipelagic province will be realized through the promulgation of a bill on customary law communities, which becomes the lex specialist for the recognition and protection of customary law communities, including spatial rights in all stages of spatial planning, namely planning, utilization and control of space utilization, also through harmonization and formulation of norms for recognition of customary law communities, territories, rights of legal subjects, as well as the concept of one map in the revision of the Spatial Planning Law and the Job Creation Law.

The development of a spatial planning law that is responsive to customary law communities, especially spatial planning rights, requires the following steps: 
1. It is encouraging the revision of Law Number 26 of 2007 concerning spatial planning in conjunction with Law Number 11 of 2020 concerning Job Creation, by accommodating the formulation of norms relating to the recognition of customary law communities as legal subjects of spatial planning, customary areas, as well as dimensions of spatial rights starting from the planning stage, utilization and controlling the use of space that contains the values of ecological justice. This revision of the spatial planning law also emphasizes spatial unity as a general principle of more effective spatial planning for archipelagic provinces;

2. This policy advocacy was also carried out to encourage the acceleration of the discussion of the Bill on Indigenous Law Communities, especially to strengthen the substance of norms regarding the stages of recognition of customary law communities, the scope of protection for customary areas related to communal ownership, management rights and area conservation as well as legal subjects related to spatial rights customary law communities at the planning, utilization and control stages of space.

\section{REFERENCES}

1. Assiddiqie, J. (2017). Konstitusi Kebudayaan dan Kebudayaan Konstitusi. Malang.

2. Erwin, M. (2018). Hak Atas Ruang Hidup Masyarakat Adat: Rekonstruksi Paradigma Hukum dan Keadilan (Studi pada Suku Orang Rimba di Taman Nasional Bukit Duabelas. Depok: Rajawali Press.

3. Haar, T.B. (2013). Asas-Asas dan Susunan Hukum Adat. Jakarta: Balai Pustaka.

4. Holleman, J.F. (1981). Van Vollenhoven on Indonesia Adat Law. Leiden: Springer SBM.

5. Koentjaraningrat. (2005). Pengantar Antropologi-Jilid II. Jakarta: Rineka Cipta.

6. Koeswahyono, I. (2012). Hukum Penatagunaan Tanah dan Penataan Ruang di Indonesia (Problematika antara Teks dan Konteks. Malang: UB Press.

7. Latif, Y. (2012). Negara Paripurna: Historisitas, Rasionalitas, dan Aktualisasi Pancasila. Jakarta: Gramedia Pustaka Utama.

8. Mahmud, P. (2007). Penelitian Hukum. Jakarta: Kencana Prenada Media Group.

9. Nurjaya, I.N. (2008). Pengelolaan Sumber Daya Alam Dalam Perspektif Antropologi Hukum. Jakarta: Prestasi Pustaka.

10. Permana, R.C. (2006). Tata Ruang Masyarakat Baduy. Wedatama Widya Sastra.

11. Rhiti, H. (2011). Filsafat Hukum Edisi Lengkap Dari Klasik ke Post Modernisme. Yogyakarta: Universitas Atmajaya.

12. Satria, et al. (2017). Laut dan Masyarakat Adat. Jakarta: Buku Kompas.

13. Sinay, S.B et al. (2021). Protection of The Rights of Indigenous People in The Archipelagic Province in Planning on Management of Coastal Areas and Small Islands Post of Law Number 11 of 2020 Concerning Job Creation. IOP Conf. Ser.: Earth Environ. Sci. 890012071.

14. Soemardiningrat, O.S. (2011). Rekonseptualisasi Hukum Adat Kontemporer: Telaah Kritis terhadap Hukum Adat sebagai hukum yang hidup dalam Masyarakat. Alumni.

15. Soepomo, R. (2013). Bab-Bab Tentang Hukum Adat. Jakarta: Balai Pustaka).

16. Subdirektorat Statistik Politik dan Keamanan. (2017). Statistik Politik 2017. Jakarta: Badan Pusat Statistik.

17. Sumardjono, M. (2018). Pluralisme Hukum Sumber Daya Alam dan Keadilan Dalam Pemanfaatan Tanah Ulayat. Yogyakarta: Fakultas Hukum Universitas Gajah Mada.

18. Thontowi, J. (2013). Perlindungan dan Pengakuan Masyarakat Adat dan Tantangannya dalam Hukum Indonesia. Jurnal Hukum lus Quia lustum, 1 (20).

19. Warman, K. (2018). Enhancing Legal Pluralism: The Role Of Adat And Islamic Laws Within The Indonesian Legal System. J. of Legal, Ethical and Regulatory Issues, 21(3).

20. Wiana, I.K. (2018). Sad Kertih: Sastra Agama, Filosofi, dan Aktualisasinya. Jurnal Bali Membangun Bali, 1(3). 